\title{
PWWP Domain-Containing Protein 2A
}

National Cancer Institute

\section{Source}

National Cancer Institute. PWWP Domain-Containing Protein 2A. NCI Thesaurus. Code C122892.

PWWP domain-containing protein 2A (755 aa, $\sim 82 \mathrm{kDa}$ ) is encoded by the human PWWP2A gene. This protein may play a role in protein-DNA or protein-protein interactions. 